\title{
The Impact of Cash Holding on Stock Price Crash Risk
}

\author{
Zhuxin Chen ${ }^{1} *$ \\ IOcean University of China, Qing Dao, Shan Dong 266000, China, chenzhuxin@stu.ouc.edu.cn
${ }^{*}$ Corresponding author. Email: chenzhuxin@stu.ouc.edu.cn
}

\begin{abstract}
This paper develops a fixed-effect model to examine the effect of cash holding on stock price crash risk with data of Chinese listed firms from 2007 to 2018 . The results indicate that corporate cash holding is positively related to stock price crash risk. Based on this consequence, it is proved that the positive relationship between operating cash flow and stock price crash risk is more pronounced. In addition, the nature of the state-owned property and "big four" auditors can strengthen the relationship of the cash holding and crash risk. This paper validates the negative effects of agency problems, confirming that the interest conflicts between stockholders and executives do increase the crash risk. It also provides a reference for investors to judge the investment risk of a firm. Moreover, it provides a new way for regulatory authorities to supervise the risk of enterprises and therefore maintain the stability of the market.
\end{abstract}

Keywords: cash holding, stock price crash risk, operating cash flow, agency theory

\section{INTRODUCTION}

The primary purposes of the stock market regulator are to maintain the stability of the market and protect small investors. Thus, factors that accelerate the crash of the market have always been a hot issue. As it is important to control the stock price crash risk, many scholars have researched the formation mechanism. Their views are mainly from the following three perspectives.

Under the perfect information hypothesis and rational man hypothesis, Pindyck and French propose a volatility feedback hypothesis, which means investors can immediately respond to the market's change $[1,2]$. They believe if the news is negative, the primary plunge of stock price will simulate people to sell the stock further so that the likelihood of stock price crash increases $[1,2]$.

However, many scholars do not believe in the perfect information hypothesis. They argue that it is just asymmetric information that leads to the crash $[3,4]$. Xu et al. find that enterprises tend to hide negative information due to the agency problems. There is a limited level of it so that once the accumulation of negative information overtakes a certain level, the bad information will flow into the market in a short period. Then the market crash will happen [5].

In addition, Bekaert finds that the crash is contagious [6]. The volatility feedback hypothesis cannot explain this conclusion as it breaks the rational man hypothesis. At present, herd behavior caused by emotional problems [7] and other factors have been considered as an explanation of this phenomenon.

Besides these three core mechanisms, to prevent the stock market crash, scholars further research the causes of the stock price crash of a single enterprise. However, most of their researches are mainly the perspective of information transparency [3], analyst behavior [5], institution investor behavior [8]. There is a lack of specific financial indicators, which can provide a new quantitative way to monitor the stock price crash risk. As a consequence, this paper will concentrate on cash indicators to predict and supervise stock price crash risk.

This paper will focus on the Chinese market owing to the following reasons. First, the Chinese stock market represents immature markets, which means it is more fragile and is easy to be influenced by external factors, such as policies [9] and irrational behavior as well [10]. Wang et al. argue that it is hard for firms to protect themselves from the uncertainty of policies, which means the influence of changing policies is inevitable [3]. For example, in 2015 Chinese government put forward a series of new strategies and directions to curb the bubble in the real estate industry and simulate industrial upgrading. However, this led to a large proportion of securities financing and over-the-counter funding. Thus, the leverage ratio surged in a short time. Between June and August in 2015, the stock market crash happened, 
during which time the Shanghai Composite Index fell from 5100 points to below 3000 points, nearly $45 \%$ within 53 trading days.

Another reason is that the Chinese stock market has a unique price limits system, which does not exist in western countries. Qu believes the price limits have made the market more volatile as it reduces the information efficiency of the market [11]. The research of Wang et al. further proves this view [12]. By comparing the volatility of the Chinese A-share market, Taiwan market, the United States market, and Hong Kong market comprehensively, they confirm that with the suspension of trading, the panic is postponed to the next trading day, thus forming a vicious circle [12].

In addition, the Chinese stock market is one of the biggest markets worldwide, and they influence each other due to the risk contagion. Herd behavior has been proved to increase the stock price crash risk of the Chinese stock market [13]. The link between the Chinese stock market and the international stock market also exists [14], which means the Chinese market will show serious chain reaction when other markets are shocked. The downward of the Chinese market will also influence other countries' stock market.

This paper chooses the data of Chinese listed firms from 2007 to 2018 as samples and finally finds that the positive relationship between the cash holding and stock price crash risk. Moreover, this paper finds that a positive relationship is more pronounced between operating cash flow and stock price crash risk. In addition, the impact of cash holding on the stock price crash risk is more pronounced in state-owned enterprises and enterprises with "big four" auditors. The result is robust in light of two kinds of robustness checks, including the fixed effects model and the increase of omitted variables.

The remainder of this study is organized as follows. The two hypotheses are developed in Section 2. Section 3 describes the research design, and Section 4 is empirical results. Further analysis and robustness checks are developed in section 5. Section 6 concludes the paper.

\section{HYPOTHESES DEVELOPMENT}

\subsection{Cash holding}

Cash is a key indicator to measure the financial situation of an enterprise. Many scholars have done abundant empirical research on it. There are three main theories about why enterprises choose to hold more cash flow: trade-off theory, pecking order theory, and agency theory. According to trade-off theory, with the increase of asset-liability ratio, marginal cost will increase with diminishing marginal revenue. Finding the balance point to maximize enterprise value is the main concern of this theory [15]. In 1984, Myers and Majluf put forward pecking order theory about investment cost, which believes corporations prefer the following financing order: retained earnings, bond, and stock [16]. However, it is arguable whether this order applies to Chinese firms. Some researches indicated that in China, firms' actual order is just reversed because the higher the debt level, the worse the economic efficiency of enterprises [17,18]. In terms of agency theory, management tends to hold more cash flow to meet their own consumption, while poor governance mechanisms can accentuate this phenomenon [19].

\subsection{Cash holding and stock price crash risk}

On the one hand, from the perspective of agency theory, tremendous cash can exacerbate selfish behaviors of the management, and the amount of cash holding may be the result of management manipulation. Thus more cash means higher risk. To prove their capacities or owing to the compensation motivation, executives tend to use more cash to invest in a risky project and introduce radical strategies, increasing the firm's risks [20,21]. Moreover, executives also have incentives to hide bad news caused by these activities at the same time so that the rise of stock price will not be influenced [5]. However, once the amount of bad news reaches the limit, there will be a huge shock to the market, and the panic will spread through the investors quickly owing to the herd behavior [10], which further exacerbates the stock price crash further risk. In addition, executives may manipulate the cash flow to cater to investor sentiment so that higher cash flows may mean higher risk. For example, they use more inventories instead of material procurement to increase the net cash flow of operating activities in the current year [22]. These are all possible agency problems in a firm, and if the governance system is not perfect, the agent problem will be more serious. For example, a senior executive may seize the enterprise resources, leading to the damage of the operation of the enterprise [23], which also has a negative influence on the operation of the firm.

On the other hand, abundant cash holding can help a firm confront uncertainty from the macro environment and reduce the stock price crash risk. When the firm is faced with an uncertain future that results from deteriorating external markets or some other factors such as bad news, the predictable larger financing constraints will make executives and stockholders tend to hold more cash to deal with the potential problems [24,25]. These firms with rich cash flow can do buybacks to keep their stock price stable, which can raise the public's confidence at the same time and thus prevent heavy selling by spooked investors [26]. Finally, the stock price crash risk can be avoided. In addition, Zou finds that the increase of stock liquidity can reduce the cost of capital structure adjustment [27]. Compared with other firms in the market, these enterprises with the relatively stable stock price are more likely to get loans from banks with faster 
speed and use other external financings to meet their own investment demand due to their liquidity in the stock market [28]. The research of Duchin further confirms the importance of cash in the crash [29]. He finds that the current assets of enterprises play a buffer role in the face of crisis [29].

Based on two potential opposing mechanisms above, this paper proposes two hypotheses as follows:

H1: The more cash the enterprise holds, the higher risk that it faces.

H2: The more cash the enterprise holds, the lower risk that it faces.

\section{RESEARCH DESIGN}

\subsection{Construction of sample}

This paper selects data from 2007 to 2018 of all Ashare listed firms from SHSE and SZSE as the analysis sample, and all data comes from China Stock Market \& Accounting Research Database (CSMAR). Referring to the research of Bai et al. [30], some samples are removed according to the following principles: (1) Firms whose annual trading weeks are less than 30 weeks are excluded. (2) The listed firms in the financial industry are excluded. (3) The listed firms under special treatment (ST firms) are excluded. Ultimately, in order to avoid the interference of extreme value on the regression results, all variables are winsorized at $1 \%$ at both tails. After the above-mentioned processing, this paper finally obtains the research sample of 19246 firm-year observations. All variables that will be used are defined in Table 1.

\subsection{Measurement of stock price crash risk}

The hypotheses to be tested are that stock price crash risk is a function of cash holding and other control variables.

$$
\begin{aligned}
& \operatorname{NCSKEW}_{t+1}\left(\text { DUVOL }_{t+1}\right)= \\
& \beta_{0}+\beta_{1} \text { Cash }_{t} \\
& +\sum_{q=2}^{n} \beta_{q}(\text { qthControlVariable })+\varepsilon_{t}
\end{aligned}
$$

where $\beta_{1}$ represents regression coefficients; $\varepsilon_{t}$ is an error term; and control variables contain $\operatorname{Ret}_{t}$, Sigma $_{t}$, Size $_{t}$, Age $_{t}$, Lev $_{t}, \mathrm{Frs}_{t}$, Growth $_{t}$, year dummies, and industry dummies. NCSKEWt and $D U V O L_{t}$ measure the stock price crash risk, whereas $\mathrm{Cash}_{t}$ represents the amount of cash holding of a firm. A positive $\beta_{l}$ suggests that Cash tends to increase stock price crash risk and vice versa.

\subsection{Variables}

\subsubsection{Dependent variable}

Referring to the methods of Kim et al., Bai et al., and $\mathrm{Xu}$ et al., this paper uses two methods to measure the risk of stock crash based on the specific return of each firm [4] [30] [8]. This paper first uses model (2) to regress firm $i$ 's specific return at week $t$ :

$$
\begin{aligned}
R_{i, t}=\alpha+\beta_{1} R_{m, t-2} & +\beta_{2} R_{m, t-1}+\beta_{3} R_{m, t} \\
& +\beta_{4} R_{m, t+1}+\beta_{5} R_{m, t+2}+\varepsilon_{i, t}
\end{aligned}
$$

where $R_{i, t}$ is the return of firm $i$ in week $t$ considering reinvestment of cash dividends, and $R_{m, t}$ is the average return of all firms in the stock market weighted by market capitalization outstanding in week $t$ corresponding to firm $i$. In addition, this paper includes lagged and ahead terms of market return in model (2) to adjust for the effect of non-synchronous stock trading. Firm-specific weekly earnings $\left(W_{i, t}\right)$ is constructed based on the regression residuals of model (2): $W_{i, t}=\ln \left(1+\varepsilon_{i, t}\right)$

Based on $W_{i, t}$, this paper constructs two proxy variables of stock price crash risk by model (3) and model (4).

(1) The negative return skewness coefficient (NCSKEW)

$$
\begin{aligned}
\operatorname{NCSKEW}_{i, t} & =-\left[n(n-1)^{\frac{3}{2}} \sum W_{i, t}^{3}\right] \\
& /[(n-1)(n \\
& \left.-2)\left(\sum W_{i, t}^{2}\right)^{3 / 2}\right]
\end{aligned}
$$

where $n$ is the number of trading weeks of stock $i$ in year t. NCSKEW $W_{i, t}$ measure the negative skewness of stock return of stock $i$. The greater the value is, the greater the risk of stock price crash is, and vice versa.

(2) The upward and downward earnings volatility (DUVOL)

$$
\begin{array}{r}
\operatorname{DUVOL}_{i, t}=\log \left\{\left[\left(n_{u}-1\right) \sum_{\text {Down }} W_{i, t}^{2}\right]\right. \\
\left./\left[\left(n_{d}-1\right) \sum_{U p} W_{i, t}^{2}\right]\right\}
\end{array}
$$

where $n_{u}$ is the number of up weeks and $n_{d}$ is the number of down weeks. Larger value of $D U V O L_{i, t}$ means higher risk.

\subsubsection{Test variable}

Followed previous studies (e.g., Bai et al.), this paper uses the ratio of total cash and cash equivalence to total assets to measure cash holding [30]. 


\subsubsection{Control variables}

This paper controls a series of variables that have been proved to influence stock price crash risk to avoid endogeneity. The first variable is $\operatorname{Ret}_{t}$, the past return of the firm, which is equal to the arithmetic average of weekly returns in year $t$ of a specific firm. As Chen et al. shows that stocks with higher volatility are riskier [31], this paper also takes the variable Sigma $_{t}$ into our consideration, which is defined as the standard deviation of the weekly returns of a specific firm in fiscal year $t$.
Hutton et al. find a positive relationship between the size of the enterprise and stock price crash risk [3]. As a result, this paper takes control of the variable Size $e_{t}$. In addition, financial leverage $L e v_{t}$ is taken into account, which is equal to the value of the total liabilities divided by total assets. Besides, this paper also controls other variables such as the growth rate of the main corporate business $\left(\right.$ Growth $\left._{t}\right)$, the natural logarithm of the age of the firm $\left(A g e_{t}\right)$, and the shareholding ratio of the corporate largest shareholder $\left(F r s_{t}\right)$. Definition and measurement method of each variable are shown in Table 1.

Table 1. Definition and Measurement of Variables

\begin{tabular}{|c|c|}
\hline \multicolumn{2}{|c|}{ Crash Risk Variables } \\
\hline$N C S K E W_{t+1}$ & $\begin{array}{l}\text { The negative skewness of firm-specific weekly returns in year } \mathrm{t}+1 \text { indicates the stock price crash } \\
\text { risk. The calculation method is shown in formula ( } 3 \text { ) }\end{array}$ \\
\hline$D_{V U O L}+1$ & $\begin{array}{l}\text { The down-to-up volatility, an indicator measures the stock price crash risk. The calculation method } \\
\text { is shown in formula (4) }\end{array}$ \\
\hline \multicolumn{2}{|c|}{ Cash Variables } \\
\hline $\mathrm{Cash}_{t}$ & The amount of cash and cash equivalent divided by total assets of the firm. \\
\hline $\operatorname{Cash} 2_{t}$ & The amount of operating cash flow divided by total assets of the firm. \\
\hline \multicolumn{2}{|c|}{ Other Variables } \\
\hline Ret $_{t}$ & The arithmetic average of weekly returns in year $t$ of a specific firm. \\
\hline Sigma $_{t}$ & The standard deviation of the weekly returns of a specific firm in fiscal year $t$. \\
\hline Sizet $_{t}$ & The natural logarithm of total assets of a firm. \\
\hline $\mathrm{Aget}_{\mathrm{t}}$ & The natural logarithm of $(1+$ firm age $)$. \\
\hline Levt & The ratio of total liabilities to total assets. \\
\hline Frst & The shareholding percentage of the largest shareholder. \\
\hline Growtht & The growth rate of a firm's main business. \\
\hline$S O E_{t}$ & A dummy variable that equals 1 if the enterprise is state-owned enterprise in year $t$ and 0 otherwise \\
\hline$B i g 4 t$ & $\begin{array}{l}\text { A dummy variable that equals } 1 \text { if the auditor of the enterprise is one of the big four in year } t \text { and } 0 \\
\text { otherwise. }\end{array}$ \\
\hline ln_aget & The natural logarithm of the age of the executive. \\
\hline Isdualityt & $\begin{array}{l}\text { A dummy variable that equals } 1 \text { if the chairman of the enterprise is also the CEO in year } t \text { and } 0 \\
\text { otherwise. }\end{array}$ \\
\hline Gender $_{t}$ & A dummy variable that equals 1 if the executive is male in year $t$ and 0 otherwise. \\
\hline
\end{tabular}

This table contains the definitions of variables used in our analysis. All continuous variables are winsorized at $1 \%$ at both tails.

\section{EMPIRICAL ANALYSES}

\subsection{Descriptive statistics}

Table 2 provides descriptive statistics for the variables of this paper. The means of crash risk measures, NCSKEW $_{t+1}$ and DUVOL D $_{+1}$, are -0.274 and -0.182 , respectively, their medians are -0.236 and -0.181 , 
respectively, and the standard deviations of them are 0.683 and 0.469 . These estimates are close to the results of Bai et al. [30], Yuan [32], and Xu et al. [5]. The mean of the cash measure $\left(\right.$ Cash $\left._{t}\right)$ is 0.153 , and its standard deviation is 0.119. The minimum of $\operatorname{Cash}_{t}$ is 0.009 , while its maximum is 0.706 , which is much higher than the minimum, showing that the corporate cash holding levels among different enterprises vary a lot. Overall, this paper finds that there is a huge difference among enterprises from the perspectives of crash risk and cash holding.

Table 2. Descriptive Statistics

\begin{tabular}{lcccccc}
\hline Variable & $\mathrm{N}$ & Mean & Std. dev. & Minimum & Median & Maximum \\
\hline NCSKEW $_{t+1}$ & 19290 & -0.274 & 0.683 & -2.306 & -0.236 & 1.456 \\
DUVOL $_{t+1}$ & 19290 & -0.182 & 0.469 & -1.306 & -0.181 & 0.963 \\
Cash $_{t}$ & 19290 & 0.210 & 0.229 & 0.010 & 0.137 & 1.381 \\
Ret $_{t}$ & 19290 & -0.001 & 0.001 & -0.005 & -0.001 & 0.000 \\
Sigma $_{t}$ & 19290 & 0.048 & 0.018 & 0.017 & 0.046 & 0.104 \\
Size $_{t}$ & 19290 & 22.080 & 1.304 & 19.480 & 21.910 & 26.000 \\
Lev $_{t}$ & 19290 & 2.772 & 0.363 & 1.609 & 2.833 & 3.434 \\
Growth $_{t}$ & 19290 & 0.468 & 0.205 & 0.064 & 0.471 & 0.939 \\
Age $_{t}$ & 19290 & 0.363 & 0.153 & 0.088 & 0.346 & 0.759 \\
Frs $_{t}$ & 19290 & 0.206 & 0.518 & -0.574 & 0.118 & 3.701 \\
\hline
\end{tabular}

Table 2 reports descriptive statistics on crash risk, cash holding, and other control variables about Chinese listed enterprises from 2007-2018. All variables are defined in Table 1.

\subsection{Correlation Analysis}

Table 3 shows the Pearson correlation coefficient matrix. The correlation coefficients of $\mathrm{Cash}_{t}$ with $N C S K E W_{t+1}$ and $D U V O L_{t+1}$ are 0.055 and 0.059 , respectively, and are both significant at the $1 \%$ significant level. This indicates that corporate cash holding is significantly and positively correlated with stock price crash risk, which corresponds to hypothesis H1. In addition, the correlations of other variables are nearly all below 0.3 , showing that there is no severe multicollinearity. In addition, the mean of VIF is 5.41, which further confirms the nonexistence of multicollinearity.

\subsection{Univariate analysis}

Tables 4 and 5 show the result of the univariate analysis with the key variables used in the study. This paper creates two groups based on whether the stock price crash risk coefficient is greater than the mean of proxy variables $\left(N C S K E W_{t+1}\right.$ and $D U V O L_{t+1}$ respectively). The results show that corporate cash holding is positively correlated with stock price crash risk and the differences are both statistically significant at the $1 \%$ level.

\subsection{Multivariate results}

Table 6 illustrates the regression results of cash holding and stock price crash risk, which derive from two distinct methods to measure the stock price crash risk. Columns (1) and (2) report the regression results without control variables, while columns (3) and (4) report the results of fixed effect model estimation after introducing control variables.

Before adding control variables, the coefficients of Cash $_{t}$ are significant at the $1 \%$ level. After introducing control variables, the coefficients of Cash $_{t}$ in columns (3) and (4) are $0.139(\mathrm{t}=2.93)$ and $0.091(\mathrm{t}=2.73)$, respectively, which are still significant at the $1 \%$ level. Therefore, $\boldsymbol{H} \boldsymbol{1}$ is primarily confirmed. The coefficients of the control variables are generally consistent with prior studies of Xu [5] and Yuan [32]. That is, enterprises with higher returns, smaller size, and younger age, are relative to higher future stock price crash risk. 
Table 3. Correlation Analysis.

\begin{tabular}{|c|c|c|c|c|c|c|c|c|c|c|}
\hline & $N_{C S K E} W_{t+1}$ & $D U V O L_{t+l}$ & $\mathrm{Cash}_{t}$ & $\operatorname{Ret}_{t}$ & Sigma $_{t}$ & Size $_{t}$ & $\mathrm{Age}_{t}$ & Levt & $F r s_{t}$ & Growth $_{t}$ \\
\hline $\begin{array}{l}N C S K E \\
W_{t+1}\end{array}$ & 1 & $0.884 * * *$ & $0.054 * * *$ & $-0.029 * * *$ & $0.030 * * *$ & $-0.117 * * *$ & $-0.054 * * *$ & $\begin{array}{l}- \\
0.057 * * \\
*\end{array}$ & $-0.033 * * *$ & $0.031 * * *$ \\
\hline $\begin{array}{l}D U V O L_{t} \\
+1\end{array}$ & $0.875 * * *$ & 1 & $0.055^{* * *}$ & $-0.023 * * *$ & $0.024 * * *$ & $-0.126^{* * *}$ & $-0.055^{* * *}$ & $\begin{array}{l}- \\
0.064 * * \\
*\end{array}$ & $-0.032 * * *$ & $0.030 * * *$ \\
\hline $\operatorname{Cash}_{t}$ & $0.055^{* * *}$ & $0.059 * * *$ & 1 & $-0.042 * * *$ & $0.042 * * *$ & $-0.195^{* * *}$ & $-0.078 * * *$ & $\begin{array}{l}- \\
0.340 * * \\
*\end{array}$ & -0.000 & $0.053 * * *$ \\
\hline $\operatorname{Ret}_{t}$ & -0.010 & -0.002 & $-0.017^{* *}$ & 1 & $-1.000 * * *$ & $0.330 * * *$ & $0.150 * * *$ & 0.009 & $0.045^{* * *}$ & $-0.036^{* * *}$ \\
\hline Sigma $_{t}$ & $0.025^{* * *}$ & $0.015^{* *}$ & $0.029 * * *$ & $-0.973^{* * *}$ & 1 & $-0.332 * * *$ & $-0.150 * * *$ & -0.010 & $-0.046^{* * *}$ & $0.036^{* * *}$ \\
\hline Size $_{t}$ & $-0.116^{* * *}$ & $-0.126 * * *$ & $-0.207 * * *$ & $0.267^{* * *}$ & $-0.311 * * *$ & 1 & $0.202^{* * *}$ & $\begin{array}{l}0.409^{* *} \\
*\end{array}$ & $0.198^{* * *}$ & 0.008 \\
\hline $\mathrm{Age}_{t}$ & $-0.054 * * *$ & $-0.054 * * *$ & $-0.123^{* * * *}$ & $0.085^{* * *}$ & $-0.107 * * *$ & $0.169^{* * *}$ & 1 & $\begin{array}{l}0.094 * * \\
*\end{array}$ & $-0.156^{* * *}$ & $-0.101 * * *$ \\
\hline$L e v_{t}$ & $-0.050^{* * *}$ & $-0.060^{* * *}$ & $-0.365^{* * *}$ & 0.001 & -0.005 & $0.394 * * *$ & $0.116^{* * *}$ & 1 & $0.041^{* * *}$ & $0.034 * * *$ \\
\hline$F r s_{t}$ & $-0.035^{* * *}$ & $-0.034 * * *$ & $0.019^{* * *}$ & $0.039^{* * *}$ & $-0.049 * * *$ & $0.233^{* * *}$ & $-0.158^{* * *}$ & $\begin{array}{l}0.037 * * \\
*\end{array}$ & 1 & 0.011 \\
\hline Growth $_{t}$ & $0.017 * *$ & $0.013^{*}$ & $0.015^{* *}$ & $-0.059 * * *$ & $0.068^{* * *}$ & -0.006 & $-0.025^{* * *} *$ & $\begin{array}{l}0.055^{* *} \\
*\end{array}$ & $0.033^{* * *}$ & 1 \\
\hline
\end{tabular}

This table shows the correlation coefficients of Cash together with $N C S K E W_{t+1}$ and $D U V O L_{t+1}$. The result shows that corporate cash holding is significantly and positively correlated with stock price crash risk.
*Indicates significance at the $10 \%$ level (two-tailed), $* *$ indicates significance at the $5 \%$ level (two-tailed), $* * *$ indicates significance at the $1 \%$ level (two-tailed).

Table 4. Univariate Analysis.

\begin{tabular}{lcccccc}
\hline Variables & G1(0) & Mean1 & G2(1) & Mean2 & MeanDiff & t-Value \\
\hline Cash $_{t}$ & 9596 & 0.147 & 9650 & 0.159 & -0.0120 & $-6.871^{* * *}$ \\
\hline
\end{tabular}

This table indicates the mean values of the variable Cash $_{t}$ when the stock price crash risk indicator
$N C S K E W_{t+1}$ is greater and less than its mean value. $* * *$ Indicates significance at the $1 \%$ level (two-tailed).

Table 5. Univariate Analysis.

\begin{tabular}{lcccccc}
\hline Variables & G1(0) & Mean1 & G2(1) & Mean2 & MeanDiff & t-Value \\
\hline Cash $_{t}$ & 9109 & 0.147 & 10137 & 0.159 & -0.0110 & $-6.556^{* * *}$
\end{tabular}

This table indicates the mean values of the variable $\mathrm{Cash}_{t}$ when the stock price crash risk indicator $D U V O L_{t+1}$ is greater and less than its mean value. $* * *$ Indicates sinificance at the $1 \%$ level (two-tailed).

\section{FURTHER ANALYSIS}

\subsection{Operating Cash Flow}

There are three resources of cash: operating activity, investment activity, and financing activity. Wu and Qiao find that operating cash flow has a significant warning effect on the occurrence of financial risk [33]. Moreover, Lee points out that investors concern more on operating cash flow [34]. Because of this, management will have more incentives to manipulate the operating cash flow than the other two kinds of cash flow. Guo et al., which indicates corporate management tends to manipulate operating cash flow due to its importance, further proving this view [35]. In addition, higher operating cash flow means more financial flexibility, showing investment ability and financing ability [36]. Therefore, to further find the mechanism of the effects that cash holding has on stock price crash risk, this paper chooses $\operatorname{Cash} 2_{t}$ as an 
alternative variable, equal to the amount of operating cash flow divided by total assets.

\subsubsection{Multivariate results}

The regression result is shown in table 7. It is obvious that the coefficient of the Cash indicator is still significant at the $1 \%$ level. Nevertheless, under the circumstance of including control variables, the coefficients of $\operatorname{Cash} 2_{t}$ are 0.330 and 0.232 , respectively, which are much higher than the coefficient of Cash $_{t}$. The consequence indicates the operating cash flow is a more effective warning signal to the stock price crash risk.

Table 6. Cash $_{t}$ and Crash Risk

\begin{tabular}{|c|c|c|c|c|}
\hline & (1) & (2) & (3) & (4) \\
\hline & NCSKEW $_{\mathrm{t}+1}$ & DUVOL $_{t+1}$ & NCSKEW $_{t+1}$ & DUVOL $_{t+1}$ \\
\hline \multirow[t]{2}{*}{ Casht $_{t}$} & $0.237^{* * *}$ & $0.170^{* * *}$ & $0.139^{* * *}$ & $0.091^{* * * *}$ \\
\hline & $(5.17)$ & $(5.42)$ & $(2.93)$ & $(2.73)$ \\
\hline \multirow[t]{2}{*}{$\operatorname{Ret}_{t}$} & & & $105.839^{* * * *}$ & $64.449^{* * * *}$ \\
\hline & & & $(4.51)$ & $(4.05)$ \\
\hline \multirow[t]{2}{*}{ Sigma $_{t}$} & & & $7.313^{* * * *}$ & $4.259^{* * *}$ \\
\hline & & & $(5.38)$ & $(4.61)$ \\
\hline \multirow[t]{2}{*}{ Sizet $_{t}$} & & & $-0.033^{* * *}$ & $-0.029^{* * *}$ \\
\hline & & & $(-6.26)$ & $(-8.16)$ \\
\hline \multirow[t]{2}{*}{$\mathrm{Age}_{t}$} & & & $-0.055^{* * *}$ & $-0.042^{* * *}$ \\
\hline & & & $(-3.45)$ & $(-3.92)$ \\
\hline \multirow[t]{2}{*}{ Levt } & & & -0.010 & -0.009 \\
\hline & & & $(-0.31)$ & $(-0.44)$ \\
\hline \multirow[t]{2}{*}{$F r s_{t}$} & & & -0.061 & -0.027 \\
\hline & & & $(-1.64)$ & $(-1.08)$ \\
\hline \multirow[t]{2}{*}{ Growth $_{t}$} & & & 0.007 & 0.003 \\
\hline & & & $(0.74)$ & $(0.41)$ \\
\hline \multirow[t]{2}{*}{ Constant } & $-0.075^{* *}$ & $-0.066^{* *}$ & $0.540^{* * * *}$ & $0.538^{* * * *}$ \\
\hline & $(-2.09)$ & $(-2.40)$ & $(4.12)$ & $(5.90)$ \\
\hline$N$ & 19246 & 19246 & 19246 & 19246 \\
\hline Industry_fixed_effect & YES & YES & YES & YES \\
\hline Year_fixed_effect & YES & YES & YES & YES \\
\hline
\end{tabular}

This table presents the results of the panel regression model of the impact of cash holding on future stock price crash risk. The dependent variables NCSKEW and DUVOL are measured over year $t+1$. The test variable is Cash $_{t}$.
*Indicates significance at the $10 \%$ level (two-tailed), ** indicates significance at the 5\% level (two-tailed), *** indicates significance at the $1 \%$ level (two-tailed).

Table 7. $\operatorname{Cash} 2_{t}$ and Crash Risk

\begin{tabular}{ccccc}
\hline & $(1)$ & $(2)$ & $(3)$ & $(4)$ \\
& NCSKEW $_{\mathrm{t}+1}$ & DUVOL $_{\mathrm{t}+1}$ & NCSKEW $_{\mathrm{t}+1}$ & DUVOL $_{\mathrm{t}+1}$ \\
\hline Cash $_{\mathrm{t}}$ & $0.284^{* * *}$ & $0.199^{* * *}$ & $0.330^{* * *}$ & $0.232^{* * *}$
\end{tabular}


$\operatorname{Ret}_{t}$

Frst

Industry_fixed_effect

19246

19246

YES

YES

Year_fixed_effect

19246

19246

This table presents the results from the ordinary least squares regression of the impact of operating cash flow on crash risk. It shows the significant positive relationship between the operating cash flow and stock price crash risk. All variables are defined in Table 1. *Indicates significance at the $10 \%$ level (two-tailed), $* *$ indicates significance at the 5\% level (two-tailed), *** indicates significance at the $1 \%$ level (two-tailed).

\subsubsection{Robustness checks}

As shown in Table 8, this paper uses two methods, including fixed effects model, and the increase of omitted variables, to find out if the regression result is reliable and robust.

First, to take the impact of individual firm characteristics on the result into consideration, this paper applies an entity fixed-effect regression model by adding a dummy variable to simulate the impact of these factors. Columns (1) and (2) show that the coefficients of Cash2 are significant at the $5 \%$ level and $10 \%$ level, respectively (with $\mathrm{t}=2.03$ and $\mathrm{t}=1.95$ respectively). It means that our results are not driven by choice of sample.

In addition, to overcome endogeneity caused by omitted variables, this paper introduces the following variables: $S O E_{t}, B i g_{t}$, Gender $_{t}, I_{n} \_a g e_{t}$, and Isduality ${ }_{t}$. These variables are defined in Table 1. Columns (3) and (4) show the coefficients of $\operatorname{Cash} 2_{t}$ are $0.322(\mathrm{t}=4.65)$ and $0.227(\mathrm{t}=4.80)$ with more omitted variables, which further verifies the robustness of our model.

Therefore, combined with the above results, the robustness of the main conclusions of this paper has been verified.

Table 8. Robustness Checks

(1)

F_NCSKEW
(2)

F_DUVOL
(3)

(4)

\begin{tabular}{|c|c|c|c|c|}
\hline & F_NCSKEW & F_DUVOL & F_NCSKEW & F_DUVOL \\
\hline Cash2 ${ }_{t}$ & $0.132^{* *}$ & $0.087^{*}$ & $0.322^{* * * *}$ & $0.227^{* * *}$ \\
\hline
\end{tabular}




\begin{tabular}{|c|c|c|c|c|}
\hline & (2.03) & (1.95) & (4.65) & (4.80) \\
\hline \multirow[t]{2}{*}{$\operatorname{Ret}_{t}$} & $99.530^{* * * *}$ & $62.225^{* * * *}$ & $105.940^{* * * *}$ & $64.605^{* * * *}$ \\
\hline & $(4.25)$ & (3.85) & $(4.51)$ & $(4.04)$ \\
\hline \multirow[t]{2}{*}{ Sigma $_{t}$} & $7.116^{* * *}$ & $4.326^{* * *}$ & $7.281^{* * * *}$ & $4.251^{* * *}$ \\
\hline & (5.16) & $(4.55)$ & (5.34) & $(4.59)$ \\
\hline \multirow[t]{2}{*}{ Size $_{t}$} & -0.016 & $-0.016^{*}$ & $-0.031^{* * *}$ & $-0.029^{* * *}$ \\
\hline & $(-1.33)$ & $(-1.95)$ & $(-5.48)$ & $(-7.44)$ \\
\hline \multirow[t]{2}{*}{$\mathrm{Age}_{t}$} & -0.091 & -0.053 & $-0.042^{* * *}$ & $-0.035^{* * *}$ \\
\hline & $(-1.27)$ & $(-1.07)$ & $(-2.62)$ & $(-3.21)$ \\
\hline \multirow[t]{2}{*}{ Lev $_{t}$} & $0.091^{*}$ & 0.054 & -0.000 & -0.003 \\
\hline & (1.83) & (1.59) & $(-0.00)$ & $(-0.13)$ \\
\hline \multirow[t]{2}{*}{ Frst } & -0.104 & -0.052 & -0.034 & -0.012 \\
\hline & $(-1.30)$ & $(-0.94)$ & $(-0.91)$ & $(-0.46)$ \\
\hline \multirow[t]{2}{*}{ Growth $_{t}$} & -0.009 & -0.006 & 0.002 & -0.000 \\
\hline & $(-0.95)$ & $(-0.89)$ & $(0.25)$ & $(-0.04)$ \\
\hline \multirow[t]{2}{*}{$S O E_{t}$} & & & $-0.058^{* * *}$ & $-0.035^{* * *}$ \\
\hline & & & $(-4.93)$ & $(-4.36)$ \\
\hline \multirow[t]{2}{*}{$B i g 4_{t}$} & & & 0.008 & 0.004 \\
\hline & & & $(0.37)$ & $(0.26)$ \\
\hline \multirow[t]{2}{*}{ Gendert } & & & 0.009 & 0.008 \\
\hline & & & $(0.66)$ & $(0.92)$ \\
\hline \multirow[t]{2}{*}{ ln_aget } & & & -0.031 & -0.014 \\
\hline & & & $(-1.04)$ & $(-0.71)$ \\
\hline \multirow[t]{2}{*}{ Isduality $_{t}$} & & & 0.005 & -0.003 \\
\hline & & & $(0.13)$ & $(-0.11)$ \\
\hline \multirow[t]{2}{*}{ Constant } & 0.204 & 0.266 & $0.616^{* * *}$ & $0.573^{* * *}$ \\
\hline & $(0.68)$ & $(1.28)$ & (3.50) & $(4.80)$ \\
\hline$N$ & 19246 & 19246 & 19246 & 19246 \\
\hline Industry_fixed & NO & NO & YES & YES \\
\hline Year_fixed & YES & YES & YES & YES \\
\hline Firm_fixed & YES & YES & NO & NO \\
\hline
\end{tabular}


It shows the results of two methods, including the fixed effects model and omitted variables, all of which verify that the regression result is robust. *Indicates significance at the $10 \%$ level (two-tailed), $* *$ indicates significance at the 5\% level (two-tailed), $* * *$ indicates significance at the $1 \%$ level (two-tailed).

\subsection{The influence of SOE and 'Big 4'}

To further the discussion, this paper considers some individual corporate characteristics. First, it introduces a dummy variable to represent the nature of the property rights of the enterprise. As the compensation of stateowned enterprises (SOE) management is not always related to the stock price. The goal of SOE is not only about the profit but also associated with policy burden such as the increase of employment, their executives have less motivation to manipulate cash flow or do other activities that increase the stock price crash risk $[37,38]$. From the beginning of 2020 to the end of June in the same year, there are 32 enterprises investigated by the Chinese securities supervision commission due to market information disclosure violations. Only three of them are SOE while the other 29 questionable enterprises are all non-state-owned.

As for 'Big 4', it refers to whether the enterprise chooses one of the four most famed accounting firms (including PwC, Deloitte, KPMG, and Ernst \& Young) worldwide as its auditor. This paper applies a dummy variable that equals 1 if the auditor of the enterprise is one of the big four to represent this feature. Song and $\mathrm{Yu}$ argue that professional auditors can help enterprises carry out internal control [39]. Jiang and Yi [40] point out that high-quality auditors help firms find executives' opportunistic behavior, which reduces the possibility of future stock price crash risk.

\subsubsection{Multivariate results}

Based on the above analysis, two sub-sample tests with dependent variable $N C S K E W_{t+1}$ are done in light of the nature of property rights of enterprises and the type of accounting firms selected by enterprises. The results are shown in table 9. The estimated coefficient of $\mathrm{Cash}_{t}$ in column (1) is 0.205 , significant at the $1 \%$ level, while the coefficient of $\mathrm{Cash}_{t}$ in column (3) is 0.132 , significant at 5\% level. Columns (1) and (3) indicate that the effect of cash holdings on stock price crash risk is more pronounced in state-owned enterprises. In addition, the estimated coefficient of Cash $_{t}$ in column (2) is 0.408 while it in column (4) is 0.119 , both of which are significant at $5 \%$ level. This indicates that holding everything constant, the feature of 'big four' auditors makes the effect of cash holdings on stock price crash risk more pronounced.

Overall, the SOE and enterprises who choose the 'big four' as the auditor have more transparent financial information, which makes the cash flow indexes better reflect the firm's situation. Therefore, these two features strengthen the relationship between cash holding and stock price crash risk.

Table 9. Sub-sample Tests

\begin{tabular}{|c|c|c|c|c|}
\hline & (1) & (2) & (3) & (4) \\
\hline & SOE & Big4 & NON SOE & NON Big4 \\
\hline \multirow[t]{2}{*}{ Cash $_{t}$} & $0.205^{* * *}$ & $0.408^{* *}$ & $0.132^{* *}$ & $0.119^{* *}$ \\
\hline & $(2.88)$ & $(2.15)$ & $(2.06)$ & $(2.43)$ \\
\hline$N$ & 9764 & 1328 & 9482 & 17918 \\
\hline Industry_fixed & YES & YES & YES & YES \\
\hline Year_fixed & YES & YES & YES & YES \\
\hline
\end{tabular}

Table 9 reports two sub-sample tests based on the nature of property rights and the type of accounting firms selected by enterprises. It shows that cash holding on stock price crash risk is more pronounced in state-owned enterprises and enterprises who choose the 'big four' as the auditor. $*$ Indicates significance at the $10 \%$ level (twotailed), $* *$ indicates significance at the 5\% level (twotailed), $* * *$ indicates significance at the $1 \%$ level (twotailed).

\section{CONCLUSION}

Based on data of listed firms from 2007 to 2018 in China, this paper studies the effect of listed corporate cash holding on its future stock price crash risk. This paper finds that corporate cash holding is positively related to its stock price crash risk. Moreover, this paper finds the relationship between operating cash flow and stock price crash risk is more pronounced. It is easier and 
more motivated for executives to manipulate operating cash flow than the other two kinds of cash flows. In addition, the nature of the state-owned property and the" big four" auditors can strengthen the relationship between the cash holding and crash risk as they make the financial information more transparent.

This paper validates that agency problems do exist in Chinese enterprises and give suggestions in two aspects. It is recommended that investors should be more concerned about the cash holding, especially the corporate operating cash flow before investment. This method is more effective for state-owned enterprises and enterprises who choose the 'big four' as the auditor. In addition, regulatory authorities should pay more attention to the supervision of cash holding to avoid the stock price crash risk in the market.

\section{REFERENCES}

[1] Pindyck R S. Risk, inflation, and the stock market, American Economic Review, (1984) 334- 351.

[2] French K R, Schwert G W, Stambaugh R F, Expected stock returns and volatility, Journal of Financial Economics. (1987)3-29.

[3] Hutton, A.P., Marcus, A.J., Tehranian, H., Opaque Financial Reports, R2, and Crash Risk, Journal of Financial Economics. 94(2009)67-86

[4] Kim, J. B., Y. Li and L. Zhang, Corporate Tax Avoidance and Stock Price Crash Risk, Firm-level Analysis, Journal of Financial Economics, 100 (2011) 639-662

[5] Xu, N.X., Jiang, X.Y., Yi, Z.H., Xu, X.Z., Analysts' conflict of interest, optimistic bias and stock price crash risk, Economic Research Journal. (2012)127140

[6] Bekaert, G., Harvey, C.R., Time-varying World Market Integration, the Journal of Finance.50(1995)403-444.

[7] Li, Z.W., Yu, P.K., Yang, J., Differences of Herd Behavior between Individual Investors and Institutional Investors, Journal of Financial Research.365(2010)77-89

[8] Xu N., Y. S. Y. Z., 2013. Herd behavior of institutional investors and stock price crash risk. Management World. (2017)31-43.

[9] Hu, An Empirical Analysis of Policy Effect, Policy Efficiency and Policy Market, Economic Theory and Economic Management. (2002)49-53

[10] Liu, X., Liu, C., Liu, S., Lu, Does Herd Behavior Increase Stock Price Volatility. System Engineering-Theory \& Practice. 34(2014)13621368
[11] Qu, W.Z., The Impact of Trading System on the Efficiency of Chinese Stock Market: An Empirical Study of Price Limit, Journal of Xiamen University.181(2007)40-47

[12] Wang, C.Y., Wang, Z.X., Price Limit, Margin Trading, and Stock Price Volatility: A Comparative Study between A-shares and H-shares, Economic Research Journal. (2017)151-165

[13] Wei, Z.H., Wang, M., The Study on the Bilateral Spillover Herd Effect on China's Stock Market Based on the Risk Contagion Theory, Modern Finance and Economics333(2017)14-27

[14] Tang, Han, An empirical study on the linkage effect between Chinese stock market and international stock market, Industrial technology economy.28(2009)129-136.

[15] Opler, T., Pinkowitz, L., Stulz, R., \& Williamson, R. The Determinants and Implications of Corporate Cash holding, Journal of Financial Economics. 52(1999) 3-46.

[16] Myers S C, Majluf, N S. Corporate financing and investment decisions when firms have information that investors do not have, Journal of financial economics. (1984) 187-221.

[17] Chen, Y., Diversification strategy, economic performance and capital structure: the explanation of equity financing preference of listed companies. (2017)9-11

[18] Huang, S.A., Zhang, G., An analysis of equity financing preference of Chinese listed companies, Economic Research Journal, (2001)12-27

[19] Jensen, M.C. Agency costs of free cash flow, corporate finance and takeovers, American Economic Review. 76(1986) 323-329.

[20] Hao, D.Y., Shi, Y.Y., Zhang, T.X., CEO Tenure, Internal Control and Stock Price Crash Risk, Journal of Central University of Finance \& Economics. 8(2020)45-60.

[21] Herrmann P, Nadkarni S. Managing Strategic Change: The Duality of CEO Personality, Strategic Management Journal, 35(2013) 1318- 1342.

[22] Lee L.F., Incentives to inflate reported cash from operation using classification and timing, Accounting Review.87(2012)1-33

[23] Harford, J., Mansi, S.A., and Maxwell, W.F. , Corporate Governance and Firm Cash Holdings in the US, Journal of Financial Economics, 87(2008)535-555. 
[24] Almeida H., M. Campello, M.S. Weisbach, The Cash Flow Sensitivity of Cash, Journal of Finance. 54(2004) 1777-1804

[25] Shen, H.H., Yu, P., Wu, L.S., State Ownership Environment Uncertainty and Investment Efficiency, Economic Research Journal. (2012)113126

[26] Li, B.N., Wang, C.X., Yang, G., Stock Repurchase and Stock Price Crash Risk: Stabilizer or Accelerator. Journal of Financial Research, 375(2021)37-50

[27] Zou, P., Monetary policy, stock liquidity and dynamic adjustment of capital structure, Audit \& Economy Research. (2015)74-82

[28] Xiong, J.C., Ye, Y.M., Stock liquidity, enterprise investment and capital allocation efficiencyEmpirical Evidence from Listed enterprises in China, Journal of Jiangxi University of Finance and Economics.103(2016)

[29] Duchin, R., Cash Holdings and Corporate, The Journal of Finance, 65(2010)955-992

[30] Bai, M., Wang, R.X., Li, W.J., Heterogeneity Risks and Corporate Cash Holdings - A Testing Based on the Crash Risks of Stock Prices, Financial Forum. 271(2018)64-80

[31] Chen, J. E. M. C. Z., Managerial power theory, tournament theory and executive pay in China, Journal of Corporate Finance. (2011) 1176-1199.

[32] Yuan, R.L., Sun, J., Cao, F., Directors' and officers' liability insurance and stock price crash risk, Journal of Corporate Finance. 37 (2016) 173-192.
[33] Wu, X.L., Qiao, N.N., Research on the relationship between cash flow from business activities and financial crisis -- Based on the empirical data of listed manufacturing enterprises in China, Journal of Shanxi Finance and Economic University. 35(2013)113-124

[34] Lee L.F., Incentives to inflate reported cash from operation using classification and timing, Accounting Review.87(2012)1-33

[35] Zeng, A.M., Leng, H.Y., Wei, Z.H., Operating Cash Flow Transparency, Market Attention and Stock Price Crash Risk, Finance and Trade Research. (2020)98-110

[36] Guo, H.T., Zhang, J.R., Li, B., Research on Motivation Selection of Cash Flow Manipulation in Listed enterprises, Journal of Management Science. (2011)89-98

[37] Bharath, S.T., Jayaraman, S., Nagar, V., Exit as Governance: An Empirical Analysis, Journal of Finance. 68(2013)2515-2547

[38] Xiong, J.C., Property Rights, Stock Liquidity and Stock Price Crash Risk, Modern Economic Science. (2015)67-77

[39] Song, X.Z., Yu, T.H., Audit Industry Expertise and Stock Price Crash Risk: A Perspective of the Importance of the Client and the Level of Internal Control, Journal of Hunan University. (2017) 64-70

[40] Jiang, X.Y., Yi, Z.H., Auditing industry expertise and stock price crash risk, Chinese Accounting Review. (2013)133-150 